\title{
Új típusú fogyasztóvédelem a felhasználók érdekében
}

A tanulmány a fogyasztóvédelemnek az Amerikai Egyesült Államokban és az Európai Unióban tetten érhető jogi és szervezeti változásain keresztül arra világít rá, hogy az új típusú technikák, az információs társadalom kihívásai mennyiben formálják át a fogyasztóvédelem hagyományos szemléletét, és hogy a normatív, állami irányítás helyett mennyire előtérbe kerül a piaci szereplőktől, a szolgáltatótól és a fogyasztótól független harmadik, civil szervezeti formában müködő szereplő közvetítő, vitarendező szerepe. A hagyományos „végfelhasználó” mint fogyasztó kategóriája helyett az ennél szélesebb, adott esetben a szolgáltatási folyamat közbülső pontján helyet foglaló közvetítő szolgáltatót is magába foglaló „felhasználó” fogalmát kell az új típusú fogyasztóvédelem fókuszába helyezni. A minden korábbinál kiszolgáltatottabb helyzetben lévő felhasználó önmagában képtelen mindahhoz a szükséges információhoz hozzájutni, amivel tudatosan és megalapozottan hozhatná meg fogyasztói döntését, ezért folyamatos támogatásra van szüksége. A felhasználói tudatosság növeli a bizalmat is az új típusú szolgáltatások igénybevétele iránt, a felhasználói bizalom pedig alapvető sarokpontja az információs társadalomnak, és ezáltal a fejlődésnek is.

\section{Szerzői információ:}

Mayer Erika

Jogász, a Budapesti Ügyvédi Kamara ügyvédjelölt-képzési programjának keretében és az ELTE Jogi Karán európai jogot, az ELTE TTK programozó matematikus hallgatóinak pedig jogi informatikát oktat. 1998 óta intenzíven foglalkozik az internettel kapcsolatos jogi kérdésekkel. A Magyarországi Internetszolgáltatók Tanácsa (ISZT) jogi képviselôjeként fontos szerepet tölt be a hazai domainjog kialakításában. Az Informatikai Érdekegyeztető Fórum (INFORUM) jogi szakértốje. Részt vett számos, az információs társadalom kiépítésére vonatkozó jogszabály kidolgozásában. Speciális kutatási területe az önszabályozás és az alternatív vitarendezés témaköre. A szerzôi jogi szakértối testület tagjaként elsősorban az internethez kapcsolódó szerzói jogi kérdésekkel foglalkozik.

Így hivatkozzon erre a cikkre:

Mayer Erika. „Új típusú fogyasztóvédelem a felhasználók érdekében”.

Információs Társadalom V, 4. szám (2005): 105-117.

$=$ https://dx.doi.org/10.22503/inftars.V.2005.4.7 $\rightleftharpoons$

A folyóiratban közölt müvek

a Creative Commons Nevezd meg! - Ne add el! - Így add tovább! 4.0

Nemzetközi Licenc feltételeinek megfelelöen használhatók. 
Mayer Erika

\section{Új típusú fogyasztóvédelem a felhasználók érdekében}

\section{Új feladatok az információs társadalomban}

Talán tudjuk, hogy az internet segítségével megnézhetjük a mozimúsort, jegyet is rendelhetünk színházba, pizzát a vacsoránkhoz, de utazást is foglalhatunk a nyári szabadságunkra, mégis félünk kihasználni ezt az új lehetôséget, félünk az új technikától, bizalmatlanok vagyunk és kiszolgáltatva érezzük magunkat. És ezzel nem vagyunk egyedül, milliók éreznek hasonlóan. Nagymamák állnak megszeppenve a számítógép eloótt, és noha tudják, hogy a világ valamely távoli pontján lévő unokájukkal ezt az eszközt felhasználva könnyen tudnának kapcsolatot teremteni, mégis félnek. Kis falvakban élő emberek szomjaznak tudásra, információra, amit a számítógép és az internet segítségével elérhetnének, de nem tudják, hogyan. Magányos emberek vágynak arra, hogy barátokat szerezzenek, beszélgessenek különféle internetes fórumokon, de tartanak a csalódásoktól, hogy magukat másnak álcázó személyek becsapják óket. Segítségre, támogatásra, megfelelố információra van szükségük ahhoz, hogy a számukra fontos, örömet adó lehetôségeket igénybe tudják és igénybe merjék venni. Szükség van tehát valami újra, új típusú fogyasztóvédelemre: a felhasználók védelmére.

A 21. század küszöbén soha nem látott mennyiségú információval szembesülünk, amelyek között egyre nehezebb eligazodni. Az új információs technológiák olyan jelenségeket eredményeznek, amelyekre nehéz megfelelóen felkészülni, a termékek bonyolult szerkezeti, technológiai újdonságai miatt a fogyasztók többé már nem rendelkezhetnek a megfelelő szakértelemmel, és ezért vásárláskor nem képesek racionálisan dönteni.

Az információs társadalom megjelenésével a következóket tapasztaljuk:

- Lényegesen bonyolultabb termékek és szolgáltatások jelennek meg, s ennek következtében egyrészt jelentôsen megnövekszik a távolság a felhasználó és a szolgáltató(k) tudásszintje (és földrajzi helyzete) között, másrészt a termékek és szolgáltatások egy lényegesen hosszabb „láncon” keresztül jutnak el a felhasználóhoz, akinek a kiszolgáltatottságát mindkét tényezố nagymértékben növeli.

- A szolgáltatások egy részének tárgyaként újfajta „termék” jelenik meg: az információ, amelynek „minőségére” újfajta, a hagyományos termékek és szolgáltatások világától eltérố követelmények vonatkoznak.

- Az információs szolgáltatások világméretûvé válása és a választék kibơvülése, amit az Internet megjelenése eredményez, ájabb veszélyforrásokat jelent, különös tekintettel egyfajta függö́ség kialakulására, melynek révén a felhasználók kiszolgáltatott helyzetbe kerülnek a szolgáltatókkal szemben.

- A hagyományos termékekhez és szolgáltatásokhoz kapcsolódó tranzakciók egy része is személytelen formában bonyolódik le, ami fokozott védelmet tesz szükségessé a résztvevók számára. 
Az információs társadalom fejlődése az állampolgári vagy felhasználói jogokra is egyre nagyobb hatással van. A meglévôk mellett újabb és újabb jogosítványok érvényesítése kerül elótérbe. A skála rendkívül széles lehet, hiszen az egyetemes szolgáltatások körének meghatározásától az egyes szerződésekben biztosított fogyasztói jogokon és az általános szerződési feltételeken keresztül a közcélú információkhoz történő hozzáférésig, az elektronikus pénzügyekig, a termékfelelôsségig, a felhasználók tájékoztatásáig, az elektronikus reklám különböző fajtáiig, de akár az egészséggel vagy bármi mással kapcsolatos etikai kérdésekig is terjedhet. Azoknak az államoknak a jogrendszerei, ahol az Internet használata nagymértékben elterjedt, normatív szabályozással is törekednek az információs szolgáltatásokat igénybe vevő felhasználók védelmének biztosítására. Ebben a körben említhetók többek között az adatvédelmi szabályok, az elektronikus kereskedelmi szerzôdésekre vonatkozó elôírások és az elektronikus aláírások. A normatív megközelítés azonban sem nem kielégítô, sem nem elégséges.

$\mathrm{Az}$ internet kielégítố és a felhasználók számára biztonságos igénybevételéhez szükség van arra is, hogy a felhasználók tudatosak legyenek, megfelelő információkkal rendelkezve csatlakozzanak a világhálóra, és élvezzék annak elónyeit. Ehhez elengedhetetlen egy olyan folyamatos és könnyen elérhető, felvilágosító-tájékoztató jellegú jogvédô szolgáltatás, ami iránt a felhasználók megalapozottan táplálhatnak bizalmat. Ezeknek a szolgáltatásoknak a megteremtésére, a civil kezdeményezésre létrejövố és állami támogatással múködố intézményekre sürgetố szükség van, ami tükrözôdik az információs társadalom kiépítését, és ezen belül az elektronikus kereskedelem elterjedését célzó valamennyi fontos dokumentumban, szülessenek azok akár az Európai Unióban, akár az Amerikai Egyesült Államokban vagy az úgynevezett „fejlett világ” bármely pontján.

\section{Fogyasztóvédelem az Amerikai Egyesült Államokban}

Az alapvetốen a klasszikus közgazdaságtani iskola által jellemzett gazdasági irányítás a minimális állami beavatkozás mellet tette le ugyan a voksot, ${ }^{1}$ ám ennek ellenére viszonylag korán, 1872-ben - éppen a hírközlés területén, a postai csalásokkal szemben - született meg az első fogyasztóvédelmi tárgyú jogszabály. Az ezt követốn felgyorsult jogalkotást 1914-re már átfogó törvény, és a fogyasztóvédelem máig legfontosabb ameri-

\footnotetext{
${ }^{1}$ Adam Smith (1723-1790) „A nemzetek gazdagsága” címmel 1776-ban megjelent mûvében fejtette ki a „laissez faire” elméletet, amely szerint tökéletes verseny esetén a termelés és a fogyasztás összhangba kerül, bizonyos árszinten a kínálat pontosan megfelel a keresletnek. Ha az egyensúly valamilyen oknál fogva felborul, a piac automatikusan helyreállítja azt. Ezért tehát tilos, sốt káros mindenfajta állami beavatkozás, így a fogyasztóvédelem is. A neoklasszikus közgazdaságtan képviselói (köztük a Nobel-díjas Milton Friedman, a chicagói iskola vezetố egyénisége, a gazdasági liberalizmus szószólója, valamint a szintén Nobel-díjas Garry S. Becker) részéról folyamatos támadások érték és érik ma is a jóléti állam beavatkozását a piaci folyamatokba. A chicagói iskola határozottan elutasítja a fogyasztóvédelmet mint a jóléti állam mindent szabályozó és az embereket, a fogyasztókat „kiskorúsító” paternalizmusának egyik megnyilvánulását. Az elmélet képviselối a fogyasztókat olyan felnốtt embereknek tekintik, akik nem tudatlanok és képesek megfelelố döntéseket hozni. Az államnak szerintük tilos az egyéni kapcsolatokba beavatkozni és az egyének helyett dönteni. Az egymással szembenálló elméletek vitája ugyan a mai napig zajlik, az azonban már eldólt, hogy a fogyasztóvédelem területén egyfajta beavatkozásra igenis szükség van.
} 
kai szervének, a Szövetségi Kereskedelmi Bizottságnak (Federal Trade Comission) a létrehozása jellemezte. További jelentôs lépésnek minôsült az 1938-ban a Kongresszus által elfogadott Élelmiszer-, gyógyszer és kozmetikumtörvény, ${ }^{2}$ amely a termékek biztonsága és a fogyasztók megfelelő tájékoztatása érdekében kötelezôvé tette a terméken elhelyezett tájékoztatást, azaz a címkézést (labelling).

Az Egyesült Államok máig legendás elnöke, J. F. Kennedy a fogyasztóvédelem történetébe is beírta a nevét, amikor 1962. március 15-én ${ }^{3}$ a fogyasztói érdekek védelmét az állami politika rangjára emelte. Kennedy elnök lefektette az alábbi négy fundamentális fogyasztói jogot, ${ }^{4}$ amelyek mindmáig minden fogyasztóvédelmi tárgyú norma alapját képezik:

- az információhoz való jog (the right to know),

- a biztonság joga (the right to be safe),

- a választás joga (the right to choose),

- a meghallgatáshoz való jog (the right to be heard).

A fogyasztói alapjogok deklarációja felgyorsította mind a jogalkotást, mind az állami és társadalmi szervezetek e téren való szerepvállalását. Reagan elnöksége alatt azonban, aki a neoklasszikus közgazdaságtan híveként véghezvitte az állami beavatkozás erốteljes visszafogását, a folyamat megtorpant. A 80-as évektól tehát csökkent a fogyasztóvédelmi tárgyú jogalkotás, az addig elért eredmények területén azonban visszalépés nem volt tapasztalható.

Az állami jogalkotás lefékezése azonban nem akadályozta meg azt, hogy a fogyasztóvédelem kérdésében egyre több társadalmi szervezet vállaljon szerepet és nagyon fontos feladatokat lásson el a piac megfelelő önszabályozása, a fogyasztók információkkal való ellátása, a piac társadalmi ellenôrzése és a jogviták „alternatív” rendezése területén. A civil szervezódések tekintetében igen nagy múlttal rendelkező Egyesült Államokban a szövetségi és tagállami szinten egyaránt igen jól kiépített állami szervezeti háló mellett szinte megszámlálhatatlanul sok fogyasztóvédelemmel foglalkozó nem kormányzati szervezet (Non-Governmental Organiæation, NGO) múködik. Ezek között az utóbbi években feltû́ntek az online piac problémáira szakosodott szervezetek is. ${ }^{5}$

Éppen ezeknek a szervezeteknek a tevékenysége is rávilágít azonban arra, hogy a klasszikus fogyasztóvédelem már csak egy részét alkotja mindazoknak az igényeknek, amelyek az információs társadalomban a felhasználók részéról felmerülnek. E szervezetek tevékenysége már nem marad meg a hagyományos fogyasztóvédelem talaján, hanem ennél szélesebb körú felhasználói érdekeket kívánnak érvényre juttatni. A sok közül az egyik ilyen szervezet a már nevében is sokatmondó „Centrum a Demokráciáért és a Technológiáért”, melynek a tevékenysége kiterjed a véleménynyil-

\footnotetext{
${ }^{2}$ Food, Drug and Cosmetic Act.

${ }^{3}$ Ezt a napot azóta a fogyasztók világnapjaként ünneplik.

${ }^{4}$ Mára e jogok száma nyolcra bốvült, és valamennyi nemzetközi szervezet, így az ENSZ is ezekre alapozza a fogyasztói jogvédelem alapelveit.

${ }^{5}$ Néhány példa: http://www.consumernet.org/, http://www.consumersvoice.org/cvoice/, http://www.cdt.org/
} 
vánítási szabadság, a személyes adatok és a magánszféra védelmére egyaránt, továbbá figyelmének a fókuszában áll a domainnevek kérdésköre is. Képviselôik megfogalmazása szerint a szervezet küldetése az, hogy ezek a jogok az új korban töretlenül érvényesülhessenek.

\section{Fogyasztóvédelem az Európai Unióban}

Az Európai Gazdasági Közösséget 1957-ben megalapító Római Szerzôdés célja olyan gazdasági térség megteremtése volt, amelyben az akadályok felszámolása lehetővé teszi az áruk, a szolgáltatások, a tóke és a munkaerố szabad áramlását, és ez a folyamat mára az egységes belsô piac megteremtését eredményezte. A fogyasztóvédelmi rendelkezések már az alapszerzódésben megjelentek, bár akkor még csak azzal a céllal, hogy a piac egészséges fejlődéséhez szükséges gazdasági verseny tisztaságát és szabadságát garantálják. ${ }^{6}$ Kezdetben tehát a fogyasztóvédelem elsôdleges célja az volt, hogy biztosítsa a megfelelố választási lehetôségeket a fogyasztói döntésekhez.

Az Európai Unió (ekkor még EGK) alapszerzôdése tehát a fogyasztóvédelmet a versenyjog felól közelítette meg. A Luxemburgban székelő Európai Bíróság döntései is tartalmaztak ugyan fogyasztóvédelmi jellegú rendelkezéseket, ám azok a tagállamok által az áruk vagy a szolgáltatások szabad áramlásával szemben emelt indokolatlan gátak felszámolására vonatkoztak. ${ }^{7}$

A komoly áttörésnek - és kifejezetten fogyasztóvédelmi tárgyú jogalkotásnak minôsüloó elsố dokumentum a Tanács 1975. április 14-én elfogadott fogyasztóvédelmi programja volt. Ekkor történt meg az európai fogyasztóvédelmi jogfejlődés alapját jelentő alábbi fogyasztói jogok deklarációja:

- jog az egészség és a biztonság védelmére,

- jog a fogyasztók gazdasági érdekeinek védelmére,

- jog a kárigény érvényesítésére,

- az információhoz és az oktatáshoz való jog,

- jog a képviseletre (a meghallgattatás joga).

A Tanács fogyasztóvédelmi programja alapján 1975 után a fogyasztóvédelem az európai jogalkotás egyik fontos területévé emelkedett, s ennek eredményeként számos irányelv született (az élelmiszer-biztonság területén, a szabványokkal kapcsolatban, az árak feltüntetésére vonatkozóan stb.).

\footnotetext{
${ }^{6}$ A Római Szerződés VI. címének 86. cikke gazdasági erőfölénnyel való visszaélésnek minősíti különösen a) a méltánytalan beszerzési vagy eladási árak és egyéb ilyen üzleti feltételek közvetlen vagy közvetett kikényszerítését, b) a termelésnek, a forgalmazásnak vagy a múszaki fejlesztésnek a fogyasztók hátrányára történố korlátozását, és c) a szerzôdések megkötésének olyan többletszolgáltatásoknak a másik fél által történố elfogadásához kötését, amelyek sem természetüknél fogva, sem a kereskedelmi szokások szerint nincsenek kapcsolatban ezen szerzôdések tárgyával.

${ }^{7}$ Lásd a Cassis de Dijon-ügyet, amelyben egy termék alkoholtartalmával szemben bevezetett indokolatlan korlátozást minốsítették a Római Szerzôdésbe ütközố elốirásnak, itt tehát a Bíróság a nemzeti fogyasztóvédelmi intézkedéssel szemben döntött.
} 
A fogyasztóvédelem 1986-ban a Római Szerződést módosító Egységes Európai Okmány révén már önálló címként jelenik meg az alapszerződésben. ${ }^{8} \mathrm{Az}$ európai jog szintjén garantált fogyasztóvédelmi elő́rások minimális követelményeknek minôsülnek, vagyis a tagállamok nem akadályozhatók meg abban, hogy szigorúbb védelmi intézkedéseket tartsanak fenn vagy vezessenek be, ezeknek az intézkedéseknek azonban a Római Szerződéssel összeegyeztethetônek kell lenniük, vagyis nem képezhetik az áruk és szolgáltatások szabad áramlásának a gátját, és nem lehetnek diszkriminatív jellegûek a más tagállamokból származó árukkal vagy szolgáltatásokkal szemben. Ezt követốen hároméves programok határozták meg az Unió fogyasztóvédelmi politikájának alakulását.

1997 októberében a fogyasztóvédelem területén további előrelépést jelentett az amszterdami csúcsértekezlet, ahol szigorúbb fogyasztóvédelmi intézkedések bevezetését és a fogyasztói érdekek magasabb szintú biztosítását írták elő. Az Amszterdami Szerződés a Közösség kötelezettségévé tette fogyasztóvédelmi politika érvényesítését.

Mára az önálló politikai területté vált fogyasztóvédelem kiemelt jelentôségét bizonyítja, hogy a Bizottságban ezt a területet külön biztos felügyeli, létrejött a Bizottság ezzel foglalkozó Fóígazgatósága, ${ }^{9}$ és a központi szervezetek mellett kialakultak a fogyasztóvédelmi egyesületek hálózatai is.

Az egységes európai fogyasztóvédelem a jogalkotás és az egységes fogyasztóvédelmi szabályozás kialakításának eszközei mellett igen nagy hangsúlyt helyez az úgynevezett „puha jog” (soft law), ${ }^{10}$ vagyis a Tanács által kiadott nem kötelező érvényú ajánlások betartására, valamint a közös szabályozás (co-regulation) és az önszabályozás (self-regulation) eszközeire is. A szabályozás - az öt fogyasztói alapjog védelmében - azt fogalmazza meg, hogy az egyes árukra vagy szolgáltatásokra vonatkozó múszaki és biztonsági elôírásoknak szavatolniuk kell a fogyasztók személyes biztonságát és egészségét. Csak biztonságos áru vagy szolgáltatás kerülhet ki a piacra, az egészséget károsító termékek reklámjainak vissza kell szorulniuk a reklámpiacról. Cél továbbá, hogy a tisztességtelen szerződési feltételek, a hátrányos kölcsönszerzôdések vagy a megtévesztố reklámok ne veszélyeztessék a fogyasztók gazdasági érdekeit, ne késztessék óket számukra hátrányos üzletek megkötésére.

Az áru megvásárlásakor vagy a szolgáltatás igénybevételekor a fogyasztók kapjanak meg minden szükséges tájékoztatást, ami elégséges döntésük meghozatalához. Rendelkezzenek jogaik és érdekeik érvényesítéséhez megfelelő ismeretekkel, az ilyen ismeretek oktatásának megszervezése fớként a mindenkori állami fogyasztóvédelem feladata. Legyen továbbá módjuk arra, hogy hibás áru megvásárlása vagy elégtelen szol-

${ }^{8}$ Római Szerzôdés XI. cím, illetve Amszterdami Szerződés XIV. cím.

${ }^{9}$ Az Európai Bizottság keretében a fogyasztóvédelemért és a fogyasztók egészségének védelméért felelôs Fốigazgatóság feladata a fogyasztói érdekek érvényre juttatása az EU jogalkotási és jogérvényesítési folyamataiban. Az élelmiszerek biztonságos fogyasztásával összefüggő témakörök mellett a Fổigazgatóság feladatkörébe tartozik az alábbi területek felügyelete: a termékek és a szolgáltatások biztonsága, az általános termékbiztonság, a távollévók közötti kereskedelem, a termékfelelősség és az árak feltüntetése, továbbá a megtévesztố reklám és a tisztességtelen szerzôdési feltételek elleni küzdelem.

${ }^{10} \mathrm{Az}$ Európai Fogyasztói Jogvédó Csoport (European Consumer Law Group, ECLG) 2001 márciusában publikált tanulmánya szerint „puha jog” (soft law) minden, amit nem a demokratikusan választott törvényhozó testületek és az általuk átruházott jogkörben eljáró szervek alkotnak. A puha jognak nem lehet polgári vagy büntetốeljárás keretében a bíróságokon érvényt szerezni. 
gáltatás igénybevétele esetén az ebból eredố kárukat a leghatékonyabban enyhítsék vagy megtérítsék.

Az Európai Unióban a fogyasztóvédelem fontos célja, hogy a fogyasztókat és érdekeik képviselóit megfelelően felkészítsék az Unióban érvényesülố politikai és gazdasági áramlatok új hatásaira. A felkészítéssel a fogyasztókban tudatosítani kell a társadalomban óket megilletô jogokat, amelyeknek a megismerése szükségessé teszi a környezettel és az egész társadalommal szemben mindenkit terhelő felelősség jobb megértését is. A közösségi fogyasztóvédelmi politika feladata továbbá, hogy az új gazdasági fejlemények - a piaci globalizáció, az információfeldolgozási technológiák megjelenése okozta kihívásokra megfelelő válaszokat adjon. A politikának ugyanis figyelembe kell vennie, hogy a piaci és a technológiai fejlódés globalizációjának eredményeként robbanásszerủen megnốtt a tömeggyártás keretében előállított fogyasztási cikkek mennyisége, $\mathrm{s}$ ezek többségét már nem az adott fogyasztók országában álítják elő. Az innovációs tevékenységnek köszönhetốen minden korábbinál bonyolultabb termelési eljárásokat vezetnek be, amelyeknek hosszú távon például az egészségre gyakorolt hatásai teljes bizonyossággal még nem láthatók előre. Az állami hatóságok között minél nagyobb fokú koordinációra és együttmúködésre, valamint a szabályozás rugalmassá tételére van szükség, hogy az új kihívásokra minél gyorsabban legyenek képesek reagálni.

Az új közösségi fogyasztóvédelmi program a korábbiaknál erôteljesebben fordul a fogyasztók számára nyújtott szolgáltatások felé, amelyeknek a gazdasági súlya az Európai Közösség gazdaságának szolgáltatás-központúvá válásával egyenes arányban nő. A szolgáltatások egészen más problémákat vetnek fel a fogyasztóvédelem terén, mint a termékek, mert az egymással helyettesíthetô szolgáltatások összehasonlítása nehezebb a fogyasztók számára, és ezért a szolgáltatások terén a verseny hatása kevésbé érvényesül. Ugyanakkor elmosódik a szolgáltatások és a termékek közötti hagyományos különbség, mert a termékek értékesítéséhez egyre nagyobb súllyal különféle szolgáltatások kapcsolódnak.

Az új fogyasztóvédelmi program célkitűzései - az Amszterdami Szerzôdés által meghatározott keretek között - megoldást kínálnak a fenti problémákra. A program az alábbiakban foglalható össze:

- a fogyasztóvédelmi szervezetek hatékonyabb múködtetése, a fogyasztók és az üzleti vállalkozások közötti hatékony párbeszéd kialakítása, hatékonyabb együttmúködés a Bizottság és a tagállamok között;

- a fogyasztók jobb tájékoztatása és képzése;

- a fogyasztók magas szintû egészségvédelme és biztonsága érdekében tudományos alapú politikaformálás, biztonságosabb termékek és szolgáltatások forgalmazása, hatékonyabb végrehajtás és ellenốrzés, gyors reagálás különféle helyzetekben; továbbá

- a fogyasztók gazdasági érdekeinek teljes körú tiszteletben tartása terén a pénzügyi szolgáltatások magasabb színvonalának megteremtése, egységes valuta biztosítása a fogyasztók számára, valamint az ehhez szükséges korszerúbb szabályozási keretek kialakítása, a szabályok hatékonyabb végrehajtása, illetve betartásuk fokozottabb ellenôrzése, végül a fogyasztók gazdasági érdekeinek erôteljesebb érvényesítése az Európai Unió politikájában. 
A jogalkotás eszköze mellett, azzal azonos szinten más eszközök (köztük az önszabályozás, ${ }^{11}$ a társadalmi szervezetek erôteljes, hatékony részvétele a fogyasztók védelmében és az alternatív vitarendezés) eszközei is elốtérbe kerültek.

Az Európai Unió Tanácsa 1999. június 28-án tette közzé állásfoglalását a közösségi fogyasztói politikáról az 1999-2001 közötti idôszakra nézve. E dokumentum 8. pontja kimondja, hogy bizonyos körülmények között az üzleti élet önszabályozása vagy a fogyasztói szervezetek és a gazdasági szereplók között létrejövô önkéntes megállapodások a jogi megoldások megfeleló kiegészítését jelenthetik, vagy - meghatározott esetekben - alternatívát jelenthetnek a jogi szabályozás számára. Az önszabályozó kódexek különösen azért lehetnek elönyösebbek, mert lehetővé teszik a piaci fejleményekre való gyorsabb reagálást. Az önszabályozásnak és az ilyen megállapodásoknak eleget kell tenniük a magas szintű fogyasztóvédelem követelményeinek, biztosítaniuk kell a fogyasztóknak a tájékoztatáshoz való jogát, és nem korlátozhatják a versenyt. Az állásfoglalás leszögezi azt is, hogy az önszabályozás és az önkéntes megállapodások megfelelő érvényesítése, valamint az eredmények figyelemmel kísérése nélkülözhetetlen a fogyasztóvédelem hatékony múködéséhez.

A fogyasztóvédelemról 2001-ben kiadott Zöld könyv értelmében az EU fogyasztóvédelmi „filozófiája” alapvetô fontosságúnak tartja a tájékoztatást, és nagy hangsúlyt kíván fektetni a fogyasztói sérelmek megelózésére. Minden olyan eljárást támogatni kíván, ami lehetôvé teszi a fogyasztói érdekek közvetlen, gyors és lehetóleg a szolgáltató által biztosított eljárások útján történô érvényesítését. Minden lehetséges eszközzel törekedni kíván arra, hogy a hosszadalmas bírósági eljárások, jogorvoslatok elkerülhetốek legyenek, és a fogyasztói érdekek rövid úton - lehetóleg nem peres eljárások révén juthassanak érvényre. Ezeknek a kritériumoknak csak hatékony önszabályozó rendszer tud megfelelni.

Az Európai Unió igen fontosnak tartja, hogy az önkéntesen elfogadott magatartási kódexek ne elszigetelten érvényesüljenek, hanem az egyes önszabályozó testületek álljanak egymással szoros kapcsolatban és folyamatosan cseréljék ki tapasztalataikat. Ugyancsak alapvetố követelmény a tagállamok hatóságainak folyamatos párbeszéde az önszabályozó szervezetekkel és azok szövetségeivel, az önszabályozó szervezetek közösségi szintû́ együttmúködése és a közösségi szintû önszabályozás.

David Byrne, az Európai Unió fogyasztóvédelmi biztosa 2000 májusában meghirdette az „e-Bizalom Kezdeményezést”. Mivel túl sok jogszabály, árujelzet és különféle címke létezik, ezek között a fogyasztónak egyre nehezebb eligazodni és meghozni a számára megfelelő döntést. Ezért szükség van arra, hogy az érdekeltek legszélesebb köre, vagyis a fogyasztók és az üzleti szereplók képviselôi együttmúködjenek, és létrehozzák a legjobb követendő gyakorlatra vonatkozó megállapodást. A kezdeményezés tehát az önszabályozást tekinti az uniós fogyasztóvédelem legjobb megoldásának.

${ }^{11}$ A Tanács által az európai audiovizuális és információs szolgáltatások versenyképességének fejlesztéséról 1998. szeptember 24-i dátummal kibocsátott Ajánlás (98/560/EC) függelékét képezố iránymutatás megadja az önszabályozó mechanizmussal szemben támasztott tartalmi követelményeket. Ezeket az alábbi négy alapvetố összetevốre bontja: az érdekelt felek konzultációja és képviselete; magatartási kódex; országos szintû́ testületek, amelyek elốsegítik a közösségi szintû együttmúködést; az önszabályozó mechanizmus országos szintú értékelése. 
2001-ben a Kangoroo Csoport megalakulásának 15. évfordulóján rendezett konferencián „Kibertér és bizalom” címmel tartott beszédében David Byrne az úgynevezett $B 2 C^{12}$ kapcsolatokra koncentrálva kifejtette, hogy nem elég fogyasztó használja ki az online hozzáférhető szolgáltatásokat, azok közül sem vásárolnak elegen, akik ezt megteszik, és a már legalább egy alkalommal online vásárlói tapasztalatot szerzett fogyasztók köréból is igen kevesen vásárolnak másodszor vagy annál többször. Ennek okát a fogyasztók bizalmatlanságában látta és ennek felszámolására megfelelő intézkedések megtételét sürgette.

A lehetséges alternatívákról szólva megemlítette, hogy létre lehet hozni például valamilyen adatbázist a „jó” szolgáltatókról, de a legfontosabb teendő olyan harmadik személyek bevonása a szolgáltatásokba, akikhez a felhasználók bármikor bizalommal fordulhatnak, s akiknek fontos feladatuk a tájékoztatás és a biztonság érzésének megerósítése is. A cél érdekében - a Bizottságnak az információs társadalomért felelős biztosával, Erkki Likannennel egyetértésben - az alábbi stratégiai lépések megtételét túzte ki célként:

a) A problémák megeloozése érdekében szükség van magatartási kódexek kialakítására, árujelzók bevezetésére és az úgynevezett „legjobb gyakorlatok” kidolgozására. A Bizottság az érdekelt fogyasztói és üzleti szervezetek bevonásával már kidolgozott egy mintaként szolgáló magatartási kódexet, amelyet közzétett a honlapján. Szükség van továbbá olyan akkreditáló szervezetek felállítására, amelyek a magatartási kódexeket jóváhagyják - ez már megtörtént Németországban, az Egyesült Királyságban és Hollandiában is.

b) A jogviták rendezéséhez lehetőséget kell biztosítani az alternatív vitarendezési eljárások igénybevételére. A Bizottság támogatja ezek bevezetését és múködését.

c) Legvégső megoldásként biztosítani kell a fogyasztó számára, hogy saját országának bíróságát vehesse igénybe jogainak érvényesítésére.

A Bizottság „e-Bizalom” stratégiája továbbá célul tû́zi ki, hogy a bizalmatlanság felszámolása érdekében támogatni kell olyan független harmadik szereplók tevékenységét, akikhez a fogyasztók megfelelő bizalommal fordulhatnak és akiktól segítséget kaphatnak felmerülő problémáik megoldására.

David Byrne gondolatai most is aktuálisak, ezt bizonyítja a 2003. november 21-én megtartott beszéde, amelyben - a lisszaboni stratégia megvalósítása érdekében - azt nevezte a legfontosabb célnak, hogy olyan „felhatalmazott fogyasztók” (empowered consumers) jelenjenek meg a piacon, aki mint egyének is képesek jogaik érvényesítésére, ehhez azonban rendelkezniük kell a megfeleló ismeretekkel, ismerniük kell a jogaikat és képesnek kell lenniük azok gyakorlására. Ehhez elengedhetetlen, hogy különféle olyan - államilag támogatott, de független - szervezetek ${ }^{13}$ jöjjenek létre és múködjenek, amelyek élvezik a fogyasঞtók bizalmát.

${ }^{12}$ B2C: az üzleti vállalkozások részéról a fogyasztók számára (business-to-consumer) biztosított tájékoztatás a szolgáltatásokról és termékekról, szembeállítva a gazdasági szereplôk egymás közötti információcseréjével (B2B).

${ }^{13}$ Az elektronikus térben felmerülô problémákra Európában különféle fogyasztóvédelmi szervezetek „szakosodtak”: Az Információs Társadalom Bizottság sajátos kezdeményezése a Dr. eCommerce elnevezésú szolgáltatás, melynek célja a fogyasztók tájékoztatása, a felvilágosítás. Ez a szervezet a hozzá intézett kérdése- 


\section{Az ENSZ fogyasztóvédelmi előírásai}

Az Egyesült Nemzetek Szervezete 1985-ben határozatot hozott arról, hogy a kormányok megfelelő fogyasztóvédelmi infrastruktúrát kötelesek létrehozni és fenntartani. Ezt a feladatot szinte valamennyi fejlett országban az állam által létrehozott és fenntartott fogyasztóvédelmi szervezetek hivatottak ellátni.

A fogyasztóvédelemnek három alapvetố funkciója van:

a) A jogalkotás befolyásolása annak érdekében, hogy a szabályozás a fogyasztók pozícióját erôsítse.

b) A fogyasztók tájékoztatása. (A fejlett fogyasztói kultúrával rendelkezô országokban ez a feladat játszik domináns szerepet. Mivel a fogyasztói jogok tiszteletben tartása természetes, a gazdasági szereplók tisztában vannak azzal, hogy a kereskedô vagy szolgáltató a munkanap végeztével fogyasztóvá válik, és ugyanolyan színvonalú munkát követel meg, mint amilyennel oó megtisztelte ügyfeleit. A felvilágosító munkához tartozik, hogy a fogyasztóvédelmi szervezetek az áruismertetố tesztek széles választékát készítteti el és bocsátja közre.

ket megválaszolja, és a kérdéseket (az azokat feltevő személy azonosítása nélkül), valamint a válaszokat is nyilvánosságra hozza. A Dr. eCommerce 1999 óta múködik. A kérdések igen változatosak: az elmúlt évek során az internettel és az információs társadalom technikai infrastruktúrájával kapcsolatban az elektronikus fizetési módok jogi helyzetétól a magánszféra védelmének kérdésein keresztül az EU elektronikus kereskedelmi marketingstratégiájáig szinte minden fontos kérdés napirendre került.

Az EEJ-NET (European Extra Judicial Network) szolgáltatásai már jóval túlmutatnak a felvilágosításon és tanácsadáson. Ez a szervezet már nemcsak a fogyasztók, hanem a szolgáltatók érdekében is tevékenykedik, és a gyors, bíróságon kívül elérhetố (alternativ) vitarendezési megoldások egyfajta adatbázisaként szolgál.

Az Európai Számítógép-felhasználók Szövetsége (Confederation of European Computer User Association, CECUA) az Európai Unió, illetve az EEA és az EFTA 12 tagállamának területén több mint félmillió felhasználót véd, akik tagjai a nemzeti szervezeteknek. Az 1982-ben alapított és az Európai Bizottsággal szorosan együttmúködő CECUA meghatározó szerepet játszik a számítógép-felhasználók érdekeinek védelmében, s ezen keresztül az információs társadalom kiépítésének elömozdításában. E független szervezet nevéhez kötôdik az internetre vonatkozó „Bill of Rights” kidolgozása is.

A civil szervezetek és az állami intézmények együttmúködésén alapuló megoldásokat tekintve az egyes tagállamokban is érdekes példákat találhatunk. Svédországban 1999-ben négy magánszemély megalakította az Internet Ombudsman intézményét, kifejezetten azzal a céllal, hogy az internetfelhasználók számára nyújtson segítséget. Ez a nonprofit szervezet ingyenes tanácsadást nyújt a felhasználóknak bármely, az internet használatához kapcsolódó kérdésben, mind technikai, mind jogi és etikai jellegú problémák esetében. Múködését a svéd kereskedelmi minisztérium, a svéd királyi bíróság és a svéd parlament által alapított Tudás Alapítvány (The Knowledge Foundation) támogatja.

Nem kell azonban ilyen messzire mennünk, hiszen a Lajtán túl Ausztria fő fogyasztóvédelmi szervezete, a VKI (Verein für Konsumenteninformation) az Osztrák Alkalmazott Távközlési Intézettel (Österreichisches Institut für angewandte Telekommunikation, ÖIAT) közösen szintén létrehozta és múködteti az Internet Ombudsman intézményét, melynek munkáját az osztrák Szövetségi Munkaügyi Kamara, a Szövetségi Igazságügyi Minisztérium, a Gazdasági és Munkaügyi Szövetségi Minisztérium, az Internetszolgáltatók Tanácsa, a Fogyasztói Tájékoztató Szervezet és a Szövetségi Kereskedelmi Kamara támogatja anyagi és más eszközökkel.

$\mathrm{Az}$ Internet Ombudsman szerepe elsôsorban az elektronikus kereskedelem fejlesztéséhez kötődik, fó célja az e-kereskedelem biztonságának növelése széles körú tájékoztatással és a biztonsági alapkövetelmények meghatározásával, így feladatai közé tartozik általános információk megadása is az interneten való vásárlás újabb módjairól és lehetốségeiról. Konkrét problémák felmerülése esetén emellett gyors, alternatív vitarendezési eljárásokat kínál. 
A vásárló már szinte otthon tud dönteni, ismeri az árucikk jellemzóit, előnyeit, de esetleges gyengeségeit is.)

c) A jogsérelmek orvosolása. Ilyenkor a fogyasztóvédelem hatóságként lép fel. Általánosan elfogadott irányelvnek tekinthetô, hogy valamilyen állapot helyrehozatala sokkal több energiát emészt fel, mint a problémák megelőzése. A jogsérelmet elszenvedett félnek bizonyosan nem jelent megfelelő elégtételt, ha a szabálytalanság miatt valakit megbüntetnek, és az sem elegendó, ha csak hosszú pereskedés után kap jogorvoslatot.

Az ENSZ által is deklarált fogyasztóvédelmi célok csak az állami szervek és a nem állami szereplók közös fellépésével valósíthatók meg. Mind az észak-amerikai, mind az európai fogyasztóvédelmi politika eljutott addig a felismerésig, hogy az állami normatív szabályozás és az állami szervezetek mellett igen fontos szerep hárul a nem kormányzati szervezetekre ( $N G O)$ is. Jól nyomon követhető, hogy az elmúlt néhány évtizedben a fogyasztók érdekeit képviseló, számukra információt és segítséget nyújtó, vagy a fogyasztói érdekeket éppen az önszabályozás és az alternatív vitarendezés eszközeivel kiszolgáló szervezetek ezrei jöttek létre és kezdték meg múködésüket a fogyasztói társadalom minden szegmensében. ${ }^{14}$

\section{A fogyasztóvédelem úi szemlélete: felhasználóvédelem}

Az európai információs társadalom kiépítését célzó eEurope $e^{15}$ programok mindenkori visszatérố eleme a felhasználói bizalom erốsítése, ami az internetpenetráció növelése és az információs társadalmi szolgáltatások elterjedése elốtt álló egyik legjelentôsebb akadály felszámolásához vezethet. Az Európai Unió - tekintettel a transzparencia és a jogharmonizáció egyik alapjának tartott szubszidiaritás elvére, az egyes nemzeti jogok fejlődési kereteit meghatározó irányelvi szabályozás mellett - jelentős szerepet szán $a$ a állami és a civil érdekvédelmi szervek együttmüködésének, az együttes szabályozásnak és az önszabályozásnak. Az információs társadalomban oly fontos bizalom kiépítését elsôsorban ezekkel az eszközökkel kívánja megvalósítani. Az információs társadalom jelenségeihez nehezen és késve alkalmazkodó, jellegzetesen konzervatív jogi normák egyébként sem alkalmasak arra, hogy az új jelenségeket megfelelô rugalmassággal kezeljék, és mind a szolgáltatók, mind a felhasználók jogait megfeleló módon védjék.

${ }^{14}$ A legfontosabb szervezetek: Consumers International (CI); Bureau Européen des Unions de Consommateurs (angol nevén: The European Consumers' Organisation), az EU Civil Fogyasztóvédelmi Szövetsége (BEUC); a Nemzetközi Piacfelügyeleti Hálózat (International Marketing Supervision Network, IMSN); a Gazdasági Együttmúködési és Fejlesztési Szervezet (Organization for Economic Co-operation and Development, OECD); az Európai Termékbiztonsági Végrehajtó Fórum - (Product Safety Enforcement Forum of Europe, PROSAFE); és a Társaság az Európai Fogyasztói Biztonságért (European Consumer Safety Association, ECOSA).

15 eEurope, 2002: Lisszabon, 2000. március; eEurope+: Prága, 2000 március; eEurope 2005: Sevilla, 2002; iEurope 2010. 
A bizalom megteremtésének és megốrzésének alapvetố eszköze az információs társadalom felhasználóinak érdekvédelme, a felhasználók különböző okok következtében fennálló kiszolgáltatottságának csökkentése.

Emellett az információs társadalmi szolgáltatások felhasználói alatt nem csupán a hagyományos értelemben vett fogyasztókat kell értenünk, hanem mindazokat, akik a modern információs társadalomban bármely formában, bármely szinten részt vesznek. $\mathrm{Az}$,e”-korszak egyik legjellemzóbb sajátossága éppen az, hogy a felhasználó rendszerint szolgáltató is, az aktív szerep egybeolvad a passzívval, és így gyarapodik, épül az információtömeget egységes virtuális térré szervező internet.

Mindezek következtében indokoltnak látszik, hogy az információs társadalomban a hagyományos fogyasztóvédelem fogalmát és hatókörét jelentósen kibővítve felhasználóvédelemról beszéljünk.

A felhasználók jogainak védelme érdekében kibontakozóban vannak azok a megoldások, amelyek az említett kívánalmaknak prớbálnak megfelelni, és emellett a felhasználók szokásain keresztül hatást gyakorolnak az információs társadalmi szolgáltatások mindennapi fejlódésére.

Míg a hagyományos fogyasztóvédelemben általában jogi szabályozásokkal, szabványokkal, minőségi elóírásokkal találkozunk, addig a felhasználóvédelmi megoldások eszköztára változatosabb képet mutat: megjelennek és egyre fontosabb szerephez jutnak az olyan önszabályozás jellegú megoldások, mint például az etikai kódexek.

\section{A felhasználók jogvédelme Magyarországon}

\section{Jogszabályi alapok}

A magyar megoldásnak sem elsôsorban a normatív szabályalkotásokra kell fokuszálnia, hanem az Európai Unió dokumentumaiban megtalálható célkitúzések jegyében az önszabályozásra és az alternatív vitarendezési megoldásokra koncentrálva kell az online tér által diktált követelményeket is kielégítoo modern felhasználóvédelmet megteremtenie.

A törekvés gyökerei fellelhetók a magyar jogrendszerben is, hiszen a 2003-tól 2006-ig tartó idốszakra vonatkozó II. középtávú fogyasztóvédelmi politikáról szóló 1012/2003. (II. 25.) kormányhatározat 2. pontja szerint az elektronikus kereskedelem területén a kormány szükségesnek tartja a fogyasztók biztonságának javítását, ennek érdekében az informatikai eszközök elektronikus kereskedelmi alkalmazásainak minôsége és biztonsága terén tanúsítási rend kialakítását, az „alternatív online vitarendezési módok" bevezetésének vizsgálatát, valamint a fogyasztóvédelmet érintố kereskedelmi jogszabályok felülvizsgálatát.

Az informatikai miniszter feladat- és hatásköréról szóló 141/2002. (VI. 28.) Korm. rendelet 5 . $§(1)$ bekezdése szerint „a miniszter az információs társadalommal kapcsolatos feladatok területén [...] b) kidolgozza az információs társadalommal kapcsolatos jogszabályokat, a gazdaság és a civil szféra szereplóinek önszabályozását elősegítő állami keretszabályozást, a bíróságon kívüli alternatív vitarendezési eljárások szabályait és fórumrendszerét". Ugyanennek a paragrafusnak a (3) bekezdése azt írja elố a miniszter 
számára, hogy az érintett szolgáltatói és fogyasztói érdekképviseleti szervezetek bevonásával gondoskodjon olyan, elektronikus úton is elérhetố ügyfélszolgálat létrehozásáról és fenntartásáról, amelyen keresztül a szolgáltatókat és a szolgáltatást igénybe vevốket tájékoztatja

a) az elektronikus úton kötött szerződésekkel összefüggő jogokról és kötelezettségekról, valamint a vitarendezési eljárásokról,

b) azon közigazgatási, egyéb állami és társadalmi szervezetek adatairól, amelyektól további tájékoztatás vagy gyakorlati segítségnyújtás kérhetô.

\section{Egy társadalmi program megualósítása}

A magyar információs társadalom kiépítésének előmozdítását céljául kitűző társadalmi szervezet, az Informatikai Érdekegyeztetố Fórum létrehozta az Infomediátor nevú informatikai felhasználóvédelmi irodát, amely az Európai Unióhoz történố csatlakozás napján, 2004. május elsején kezdte meg érdemi tevékenységét.

Az Infomediátor felállítását átfogó kutatás előzte meg, amelynek során áttekintettük a hasonló feladatokat ellátó külföldi felhasználóvédelmi szolgáltatások múködését, és ezek tapasztalatainak figyelembevételével határoztuk meg az Infomediátor tevékenységi területét és múködésének elveit. A nemzetközi példáktól annyiban eltérố, egyedülálló és példamutató az Infomediátor, hogy múködése szélesebb körre terjed ki, mint a hasonló külföldi intézmények (az osztrák, német vagy svéd Internet Ombudsman, a német $V Z V B$, a francia „Kiberfogyasztók Bizottsága” stb.) tevékenysége. Míg a külföldi szervezetek elsősorban a fogyasztókat az elektronikus kereskedelem területén érô sérelmek kiküszöbölésére törekszenek, illetve erre a célra múködtetnek alternatív vitarendezési szolgáltatásokat, addig az Infomediátor ennél jelentôsen szélesebb körú szolgáltatásokat nyújt.

Az Infomediátor célja, hogy tevékenységével elốsegítse az informatikai szolgáltatások iránti bizalom növekedését, támogassa az internet és az információs technológiák tudatos és biztonságos használatát, s ennek eredményeként csökkentse a digitális szakadékot és növelje a hazai internetpenetrációt. Az Infomediátor a közigazgatási eljárás megindítása elótt tud segíteni a hozzá fordulóknak, így számos esetben elháríthatja az eljárás felesleges megindítását, amennyiben pedig az mégis szükséges, rögtön a megfelelő hatósághoz irányíthatja az ügyfelet. Az Infomediátor így jelentôsen tehermentesítheti azokat a hatóságokat, amelyekhez a sértettek informatikai szolgáltatásokkal kapcsolatban fordulnak. Az Infomediátor múködési elveit és az elsố év múködési tapasztalatait a melléklet mutatja be.

\section{Következtetések}

Az Infomediátor múködése jó példa arra, hogy a szakmai szervezốdés hogyan tud gyorsan és rugalmasan, az önszabályozás és alternatív vitarendezés eszközeivel reagálni olyan kihívásokra, amelyek az új technológiák gyors fejlódése miatt a normatív rendezés számára egyáltalán nem, vagy csak igen lassan és nehézkesen kezelhetók. Jó példája 
továbbá mindannak, amit az Európai Unió is célul tûzött ki az új típusú fogyasztóvédelem területén: megjelent egy megfelelő semleges harmadik fél, amely hidat tud képezni a felhasználók és a szolgáltatók között, és ezért alkalmas arra, hogy mindkét oldal bizalmát élvezve rendezze a felmerüló jogvitákat. Az Infomediátornak komoly presztízse alakult ki a szakmai szervezetek körében, ezért fellépése esetén a szolgáltatók sokkal nagyobb készséget mutatnak a vita gyors és méltányos rendezésére, mint akkor, ha a felhasználó a hagyományos bírói úton próbálja érvényesíteni a jogait.

Az Infomediátor - amellett, hogy a szolgáltató vagy kereskedő és a vele szemben álló felhasználó kapcsolatában közvetítóként rendezi a jogvitákat - konkrét jogsérelem nélkül is kiáll olyan ügyek érdekében, ahol a felhasználó joga bármely módon sérelmet szenvedhet. Így például 2004 májusában állásfoglalást adott ki arról, hogy a jogszabályokhoz történő hozzáférés állampolgári alkotmányos alapjog, amit az államnak az interneten keresztül, rendezett adatbázisban és ingyenesen kellene biztosítania. Ugyancsak az Infomediátor fellépésének eredményeként alakították át az Igazságügyi Minisztérium honlapját, és ennek következtében mindenki számára egyszerúbben vált elérhetóvé az európai jogszabályok magyar nyelvú adatbázisa. 